\title{
Active Learning Management in Daily Mathematics and Statistics Course for Communication Arts Students
}

\author{
Apinya Ingard
}

\begin{abstract}
This research was aimed to 1) study the learning achievement from active learning management in daily mathematics and statistic course, 2) to develop the learning achievement toward the learning achievement standard for higher education, and 3) to evaluate the students' opinion who studied via active learning management in daily mathematics and statistic course. The 220 population was the second year students of communication arts, Silpakorn University, who were studying in semester 1, academic year 2015. Data was statistically analyzed by percentage, mean, and standard deviation. The research findings were that 1) the learning achievement of the students in theory approach gained the standard of curriculum, 2) the learning achievement in daily mathematics and statistics course in overview of 5 approaches was at the level of "high", 3) the opinion of the students who studied via active learning management were that the learning management in daily mathematics and statistic course was useful and valuable to the students. The students studied happily, the activity was fun and not serious to learn. The students gained knowledge and query skill, interaction with friends and instructor. And the students were satisfied with learning evaluation.
\end{abstract}

Index Terms-Active learning, statistics course, achievement, learning management.

\section{INTRODUCTION}

Higher Education in Thailand was conducted and controlled by the Ministry of Education. The national education act (edition 2) B.E. 2545, group 4 unit 22, mentioned on educational management that all learners should be able to learn and develop themselves. The learners were the most important. The process of education management must support learners to develop by natural and potential of individual. In unit 24 mentioned (1) to provide the content and learning activity related to the interest and the ability of learners by the principle of individualization (2) to provide the skill, thinking process, management, situation and knowledge application to prevent and solve problem, and (3) to provide learning activity by real situation, do practical, think, reading skill and continual learning. [1]

This is harmonized to Thailand qualifications framework for higher education: $\mathrm{TQF}$ that aimed to enhance learners to gain potential in moral, knowledge, intellectual skill, interpersonal and responsibility skill, numeric analysis thinking skill, communication and information technology application. Those of characteristics are the learners' ability to gain self-directed learning and long life learning as the

Manuscript received November 18, 2017; revised May 14, 2018.

A. Ingard is with the Faculty of Information and Communication Technology, Silpakron University, Japan (e-mail: apinya.i@hotmail.com). criteria of institution quality assurance in higher education level which mentioned the vision of educational institute that the production of graduates or the learning management to serve knowledge and skill for learners. The learning process should be student- centered. The instructors should adapt the learning management related to social development, technology, and the learning method of learners. The instructors changed role from transferor to be the mentor instead. The main objective is to develop learners to seek for knowledge and apply the learning skill to understand and become meaningful learning.

Active learning is the instructional model suited to the learning objective to enhance the students' understanding and knowledge application for daily life. Active learning also enhances the students eager for learning and stimulates to think. It is better than the traditional teaching for the learners to remember what the teachers taught. Active learning can upgrade the learning achievement of the learners and satisfy the learners in terms of learning activity in cooperative learning. The learners can learn by doing not only get knowledge by only listening to the teachers or passive learning. [2] As Paitoon Sinlarat [3] mentioned about didactic method of teaching is passive and was unable to response new approach of higher education. The instructional model conversed to focus on student centred approach and constructivism or learning process creation. [4]

This concept is harmonized to the learning management to enhance the correct concept and reach the permanent knowledge. Learners should be able to connect knowledge to their life. The learning atmosphere should be funny and be able to integrate for advance benefits which caused by the learning by doing activity. [5]

The recent educational research and educators agreed that "The learners should learn by doing more than listening". The learners should have reading skill, writing skill, discussion ability, problem solving skill. The most important is to be able to think in analytical, synthetic and evaluation level. [6] [7]

However the strategy to support active learning is the learning process to give opportunity for learners to do in real situation and think in what they are learning. [6] [8]

A course "Daily mathematic and Statistics" in Communication Arts Curriculum is one of the basic requirement for all of the students. The problem encountered for social and humanity science reflex that the students are not able to integrate and apply in real life or integrate with another course. This was caused by the prior teaching methodology which the learners were only knowledge receiver. The knowledge from learning is not able to apply effectively. The researcher is interesting to apply active 
learning management for 220 students of communication arts who were registered this course in the first semester of academic year 2015 .

The course "Daily mathematic and Statistics" concerns the data collection and analysis to gain information which is the main objective of this course. The data analysis is the content that the learners do not understand and cannot select the correct and appropriate method to manipulate including the interpretation of data analyzed. By the problem mentioned above, the researcher tried to design the learning activity by active learning to create the learning atmosphere of collaboration, question and answer learning activity, group processing, learning by doing activity to match the authentic situation, presentation, knowledge sharing among learners and teacher. The teaching method designed is called active learning. The learning outcome is inspected toward the learning achievement standard for higher education in daily mathematic and statistics course.

The learning achievement includes 5 aspects: Moral and ethics (attitude domain) - the evaluation was done by task assignment, and disciplinary in participating activity with $10 \%$, knowledge (cognitive domain) - the evaluation was done by learning achievement test with 55\%, intellectual skill, interpersonal skill - the evaluation was done by group processing, and numeric analysis skill, communication and information technology application skill (psychomotor domain) - the evaluation was done by learning by doing activity and presentation with $35 \%$ and evaluated by peer assessment.

The researcher designed and integrated the active learning to make the learning process lively and stimulated the students of communication arts to develop themselves toward the learning achievement standard for higher education. The researcher expected to use active learning management in daily mathematic and statistics course and applied for other course to gain the other learning behavior of the learners as well.

\section{RESEARCH OBJECTIVES}

1) To study the learning achievement of the second year students of communication arts, Silpakorn University, who studied via active learning management

2) To develop the learning achievement toward the learning achievement standard for higher education

3) To evaluate the students' opinion who studied via active learning management in daily mathematics and statistic course

\section{RESEARCH METHOdOLOGY}

This research was classroom action research that hade one group design.

\section{A. Population}

The 220 population were second year students of communication arts who were studying in semester 1, academic year 2015, registered in daily mathematic and statistics course.

\section{B. Research Instruments: The Research Instruments Were as Follow}

1) Active Learning Lesson Plan - there were 15 lesson plans with active learning activities; Question and Answer, Group processing, Individual Learning with Direct Experience and Authentic Situation which followed by TQF (Thailand qualifications framework) criterions.

2) Learning achievement test composed for pretest and posttest - the objective test had 40 items and subjective test had 5 items.

3) The evaluation form of opinion to active learning management composed of 5 approaches toward standard qualification of higher education of national education or TQF in daily mathematic and statistics course. The test was 5 rating scale include "1 scale was least", "2 scale was little", "3 scale was average", "4 scale was much", and "5 scale was most".

\section{Development of Research Instruments}

The validity of instrument was investigated by 3 experts. The 15 active learning lesson plans and learning achievement test composed of 5 approaches toward standard qualification of higher education of national education or TQF, and evaluation form of opinion to active learning management were presented and criticized by the experts. The suggestion of the experts was used to adapt and develop the research instruments.

The reliability of the research instrument; learning achievement test composed of 5 approaches toward standard qualification of higher education of national education was tried out with 30 students who were studying in the academic year 2014. The data tested was analyzed for alpha- reliability coefficient between $0.758-0.925$. The learning achievement test was analyzed for reliability using KR-20 was at 0.875 .

The difficulty and discrimination of learning achievement test was done by testing with 30 students and the difficulty was between $0.30-0.60$ and the discrimination with more than 0.2 was used for this research.

\section{Data Analysis}

The analysis of only descriptive statistics was used frequency, percentage, means and standard deviation. The data was presented in tables and description.

The content analysis was used to explain the opinion of students.

The criterions of opinion level on active learning management were as follow:

4.21-5.00 referred to agree at the level of "most"

3.41- 4.20 referred to agree at the level of "much"

2.61- 3.40 referred to agree at the level of "average"

1.81- 2.60 referred to agree at the level of "little"

$1.00-1.80$ referred to agree at the level of "least"

\section{RESEARCH FINDINGS}

A. The Learning Achievement of Communication Arts Students, Silpakorn University, Who Studied via Active Learning Management in Daily Mathematics and Statistic Course (See Table I) 
TABLE I: THE LEARNING ACHIEVEMENT OF STUDENTS

\begin{tabular}{ccccc}
\hline \hline Score & Grade & Meaning & Amount & Percentage \\
\hline $85.00+$ & A & excellent & 46 & 20.9 \\
$80.00-84.99$ & B + & very good & 78 & 35.5 \\
$75.00-79.99$ & B & good & 55 & 25.0 \\
$68.00-74.99$ & C + & quite good & 19 & 8.6 \\
$60.00-67.99$ & C & fair & 13 & 5.9 \\
$55.00-59.99$ & D + & poor & 7 & 3.2 \\
$50.00-54.99$ & D & very poor & 2 & 0.9 \\
$<50.00$ & F & fail & 0 & 0 \\
\hline \hline
\end{tabular}

Mention to Table I, the learning achievement of second year, communication arts students, Silpakorn University, who studied via active learning management in daily mathematics and statistics course was as follow: 46 students $(20.9 \%)$ gained the learning achievement at the level of "excellent" (the score was more than 85), 78 students (35.5\%) gained the learning achievement at the level of "very good" (the score was between $80.00-84.99$ ), 55 students $(25 \%)$ gained the learning achievement at the level of "good" (the score was between 75.00-79.99), 19 students (8.6\%) gained the learning achievement at the level of "quite good" (the score was between 68.00-74.99), 13 students (5.9\%) gained the learning achievement at the level of "fair" (the score was between 60.00-67.99), 7 students (3.2\%) gained the learning achievement at the level of "poor" (the score was between 55.00-59.99), and 2 students (0.9\%) gained the learning achievement at the level of "very poor" (the score was between 50.00-54.99).

\section{B. The Learning Achievement Test According to Five} Approaches toward Standard Qualification of Higher Education of National Education of Communication Arts Students, Silpakorn University

The development of learning achievement according to five approaches toward standard qualification of higher education of national education in daily mathematics and statistics was shown in Table II

TABLE II: LEARNING ACHIEVEMENT ACCORDING TO FIVE APPROACHES

\begin{tabular}{lccc}
\hline \hline \multicolumn{1}{c}{ Learning achievement } & Mean & S.D. & Results \\
\hline Moral and ethics & 4.15 & .54 & much \\
Knowledge & 4.20 & .57 & much \\
Intellectual skill & 4.19 & .53 & much \\
Interpersonal skill & 4.35 & .53 & most \\
Numeric analysis skill & 4.40 & .57 & most \\
\hline \hline
\end{tabular}

Table II showed about the analysis of learning achievement according to five approaches toward standard qualification of higher education of national education, the students of communication arts who studied daily mathematics and statistics course gained the learning achievement at the level of "most" in numeric analysis skill, communication, information technology application, and interpersonal skill approach respectively with means of 4.40 and 4.35 (S.D. $=.57$, and .53) whereas the knowledge, intellectual and moral approach gained the learning achievement at the level of "much" with means of 4.20, 4.19 and 4.15 respectively (S.D. $=0.57,0.53$ and 0.54 ).

C. The Opinion of Communication Arts Students, Silpakorn University, to Active Learning Management in Daily Mathematics and Statistics Course

The evaluation on opinion of communication arts students, Silpakorn University, to active learning management in daily mathematics and statistics course found that active learning management was useful and valuable to the students. The students participated in the learning process happily. The students gained knowledge and skill for searching knowledge and interacted with friends and instructors and satisfied with the learning evaluation.

\section{DISCUSSION}

The study on learning achievement of second year communication arts students, Silpakorn University, who studied via active learning management in daily mathematics and statistics course, found that all of the students passed the test according to the criteria. Most of the students gained the learning achievement at the level of "excellent". This might be caused by the learning process of active learning management that designed to cooperate in learning, group process for analysis and presentation and also the raising of issue for asking and answering. The learning process could enhance the learners to gain knowledge, understood the lesson and be able to apply in real life and finally for course evaluation.

This research was harmonized to the research of Yananda Siripatthada [9] that studied a development of behaviour and learning achievement of the students who studied via active learning in a principle of marketing course. The result of the study was that the students had better development in knowledge and understanding. The behavior on theory and practice of the students was in accordance with the objectives. The same as research of Sirirat In-sook, Apichart Atchariyasakchai, and Ronnahop Imthap [7] that studied on active learning in Biology course toward the learning achievement standard for higher education with Boromarajonani Buddhachinaraj College of Nursing's students and found that the students who studied with active learning process, all passed the criteria at $100 \%$.

The learning achievement standard for higher education in daily mathematics and statistics course of communication arts students found the numeric analysis, communication and information technology application skill was at the level of "highest". This was caused by the learning process that designed for the students to search information, applied the information technology and communication, and also used social networking system for gathering data and analyzed the data by statistical science and presented the knowledge These learning activities helped the students to develop themselves and did the best.

This research was harmonized to research of Sirirat In-sook, Apichart Atchariyasakchai, and Ronnahop Imthap [7] that also found that active learning could be able to enhance or develop the learners in any approach of learning achievement toward the learning achievement standard for higher education. But some of the difference in learning achievement on interpersonal skill was at the level of "highest". For the research of Chalerm Wongjuntra, Nataya Puengsawang, and Manthina Japha [10] that followed up the quality of graduates from Bachelor of Nursing Curriculum found that the Air Force nursing students had numeric analysis, communication and information technology application skill at the level of "much". 


\section{Suggestions}

A. Suggestion from the Research Findings - The Research Finding Can Be Applied for Instructional Management in These Areas

1) The active learning management should be applied in others course / field of study. The environment and individualization should be considered. The class should have multi-level of learners' intelligence; (smart average and poor).

2) The curriculum administrator of communication arts of Silpakorn University and the stakeholders should support to apply active learning for lively learning for the learners to gain knowledge and apply knowledge in daily life.

3) The curriculum administrator, the institute administrators, and instructors should prepare adequate facilities for learning management such as computers, database, and effective internet signal.

4) The instructors should advise the group activity to work in team to accomplish the learning objective in advance.

\section{B. Suggestion for Further Research}

The research in other field / course should be done to develop learners in all approach of learning achievement toward the learning achievement standard for higher education.

\section{REFERENCES}

[1] Office of the National Education, National Education Act B.E. 2542 , Bangkok, 1999.
[2] J. Sweller, "The worked example effect and human cognition: Learning and Instruction," New Jersey: Educational Technologies, 2006.

[3] P. Sinlarat, Research Based Learning, Bangkok: Faculty of Education, Chulalongkorn University, 2002.

[4] J. A. Spencer and R. K. Jordan, "Learner centred approaches in medical education,” BMJ, vol. 318, pp. 1280-1283, 1999.

[5] J. Attabhorn and P. Karaneekit, "A development of online active learning to enhance learning behavior of graduate students," Educational Electronics Journal, vol. 9, pp. 122-136, 2015.

[6] C. C. Bonwell and J. A. Eison, "Active learning: Creating excitement in the classroom," ERIC Digest, May 2012.

[7] S. In-sook, A. Atchariyasakchai, and R. Imthap, "Active learning in Biology course toward the learning achievement standard for higher education in Boromarajonani Buddhachinaraj College of Nursing," Report on the $3^{\text {rd }}$ National Conference and Research, Step to $2^{\text {nd }}$ Decade: Integration of Knowledge for Sustainability, 2016.

[8] R. E. Mayer, "Should there be a three-strikes rule against pure discovery learning? The case for guided methods of instruction," Americal Psychologist, vol. 59, no. 1, January 2004, pp. 14-19, 2004.

[9] Y. Siripatthada, "A development of learning behavior and learning achievement of the students in principle of marketing course using cooperative learning," Bangkok: Suan Sunandha Rajabhat University, 2013.

[10] C. Wongjuntra, N. Puengsawang, and M. Japha, Report on Following up the Quality of Graduates from Bachelor of Nursing, Revised Curriculum B.E. 2546, Bangkok: Air Force Nursing College, Department of Air Force Medicine, 2013.

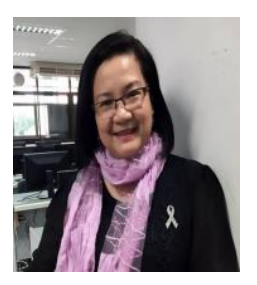

Apinya Ingard was born on September 26, 1969, in Phang-nga, Thailand. She received her Ph.D. in research and statistics in cognitive science, Burapha University, Thailand in 2009. Currently, she is a full-time lecturer for undergraduate studies in the business information technology program, Faculty of Information and Communication Technology, Silpakorn University. Her particular field of interest includes using the applied statistics in any fields such as education, information technology, communication arts, psychological, behaviors, and others. Moreover, she is interested in business intelligence study. 